\title{
Morphological and Scanning Electron Microscopy Studies of the Stomach of the Egyptian Fruit Bat (Rousettus aegyptiacus)
}

\author{
Estudios Morfológico y de Microscopía Electrónica de Barrido \\ del Estómago del Murciélago Egipcio de la Fruta (Rousettus aegyptiacus)
}

Mohamed M. A. Abumandour ${ }^{1}$ \& William Pérez ${ }^{2}$

ABUMANDOUR, M. M. A. \& PÉREZ, W. Morphological and scanning electron microscopy studies of the stomach of the Egyptian fruit bat (Rousettus aegyptiacus). Int. J. Morphol., 35(1):242-250, 2017.

SUMMARY: This study was performed to investigate the histomorphological characters of the Egyptian fruit bat stomach using the light and scanning electron microscope. The stomachs of fourteen adult normal healthy Egyptian fruit bats of both sexes were used. Stomach was tubular with an elongated fundic part and a long narrow pyloric part. Internally, the superficial epithelium was disposed in filiform form, the longitudinal rugaes extended throughout the length of the stomach, their numbers were high but they were thin and branched in the fundic region, while in the cardiac and pyloric region reached to 3 or 4 thick longitudinal and not branched rugaes. Under the scanning electron microscopy, we found differences in the appearance of middle part with the peripherical part of the fundic region, like the appearance of honeycomb buildings in the middle part different to round elevated formations at the periphery of fundic region. At high magnification of cardiac region, there was an aggregation of epithelial cells without regular shape, while there were elevated mountains areas in the pyloric region. We concluded that the stomachs of Egyptian fruit bat had special characters different to other mammals.

KEY WORDS: Anatomy; Chiroptera; Digestive system; SEM.

\section{INTRODUCTION}

Bats are very interesting mammal due to its peculiar character in its life style and is the only mammalian animal that have the ability to flight and feeding during the flight (Wilson \& Reeder, 1993; Altringham et al., 1996). Bats were classified in order Chiroptera, suborder Megachiroptera, and family Pteropodidae. Pteropodidae depend on the fruit, flowers, nectar and pollen in its feeding. The genus Rousettus have only one species in Egypt called Rousettus aegyptiacus (Altringham et al.). Egyptian fruit bat found throughout Africa, except in the Sahara desert, and throughout the Middle East, as far east as Pakistan and northern India.

This species of bat have relatively little attention especially in its gastrointestinal morphology when compared to New World bats. To know the nutritional ecology of any animal, it is necessary to understand the morphology of its digestive tract (Martínez del Río et al., 1994). Bats are characterized by having a number of different feeding strategies, including frugivores, insectivores and blood sucking (Forman, 1990). Egyptian fruit bats are frugivorous, consuming large amounts of fruit each night. Most of their diets tend to consist of unripe and insect- and fungus-damaged fruit, which allows them to thrive in habitats where ripe fruit are not available year-round. The stomach of bat is adapted according to; food type and feeding behavior as noted by some authors (Rouk \& Glass, 1970; Okon, 1977). The interesting point is the fact that the bats are highly specific in their dietary habits and the structure of the stomach has great adaptation to the dietary habit as noted by (Bhide, 1979).

The anatomy of the stomach of numerous species of Microchiroptera has been examined by many authors (Schultz, 1965; Rouk \& Glass; Forman, 1972, 1973; Kamiya \& Pirlot, 1975; Madkour, 1977) to determine its general morphology and to understand its systematic anatomy for comparison and to consider functional adaptation and evolutionary changes. However very limited attention has been paid to the stomach of the Megachiroptera (Schultz, 1970; Halstead, 1975; Okon; Bhide; Madkour et al., 1982); and there is no published

\footnotetext{
${ }^{1}$ Anatomy and Embryology Department, Faculty of Veterinary Medicine, Rashid, Edfina, Behera, Egypt.

${ }^{2}$ Área de Anatomía, Facultad de Veterinaria, Universidad de la República, Lasplaces 1620, 11600 Montevideo, Uruguay.
} 
information about the stomach of Egyptian fruit bat, and in general there are few morphological studies on these species (Madkour, 1976; Abumandour, 2014; Abumandour \& El-Bakary, 2013).

The aim of this study was to elucidate the topographical anatomy and morphological characteristics of the stomach in adult Egyptian fruit bats to assess the level of their gastric adaptation to the feeding type.

\section{MATERIAL AND METHOD}

Samples. This study was carried out with stomachs of fourteen healthy adult Egyptian fruit bats, of both sexes collected from fruit farms and old houses from Edfina, Rashid, Behera government, Egypt. The specimens were handled and treated according to the local Ethical Board guidelines of Alexandria University, Egypt.

For gross morphology. Six stomachs of healthy adult animals of both sexes were used to demonstrate the topographic anatomical position and the external and internal gross morphological features of the stomach. Three bats were used fresh, and three were formalized. All stomachs used in this study were opened with a longitudinal section in the great curvature; the specimens used for macroscopic observations were fixed in a solution with $10 \%$ formalin.

For histological studies. Four stomachs of healthy adult Egyptian fruit bats of both sexes were used in the histological studies then the stomachs were divided into several segments. Subsequently each segment was fixed in a solution with $10 \%$ neutral buffered formalin for 48 hs, then they were dehydrated in an ascending grades of ethyl alcohol $70 \%, 80 \%, 90 \%$ for 7 hs followed by absolute alcohol (I, II, III) for $3 \mathrm{~h}$, and then cleared in xylol I, II and III for $30 \mathrm{~min}$ in each one till transparency. Samples were immersed in melted paraffin wax (paraffin I, II, III) for $60 \mathrm{~min}$ in each one at melting point of 55-60 ${ }^{\circ} \mathrm{C}$ in oven to replace the xylol inside the tissues, then they were poured in a mould and left to cool. The segments of stomach in the paraffin block were sectioned at $5 \mu \mathrm{m}$ thickness using the microtome. The sections were stained by Haematoxylin and Eosin (H \& E) as demonstrated by (Bancroft \& Cook, 1984). Sections were then dehydrated in ascending grade of ethyl alcohol $70 \%, 80 \%, 90 \%$ followed by absolute alcohol (I, II, III) for (3-5 min) in each one, cleaned in xylol (I, II, III) for 2-5 min in each one, and finally they were mounted in Canada balsam and covered with a cover slip.
For scanning electron microscopy. For scanning electron microscopical (SEM) observations, samples were taken from three different regions of the stomach (fundic, cardiac and pyloric) of four adult Egyptian fruit bats of both sexes, these were fixed in $2 \%$ formaldehyde, $1.25 \%$ glutaraldehyde in $0.1 \mathrm{M}$ sodium cacodylate buffer, $\mathrm{pH} 7.2$ at $4{ }^{\circ} \mathrm{C}$. Once fixed, the samples were washed in $0.1 \mathrm{M}$ sodium cacodylate containing $5 \%$ sucrose, processed through tannic acid, and finally dehydrated in increasing concentrations of ethanol (15 min each in 50, 70, 80, 90, 95 and $100 \%$ ethanol). The samples were then critical point dried in carbon dioxide, attached to stubs with colloidal carbon and coated with gold palladium in a sputtering device. Specimens were examined and photographed with a JEOL scanning electron microscope operating at $15 \mathrm{KV}$, at the Faculty of Science, Alexandria University.

\section{RESULTS}

\section{Morphological studies}

Anatomical position of the Egyptian fruit bat stomach: The stomach (Gaster) of the Egyptian fruit bat was located in the intrathoracic part of the abdominal cavity and was not attached to the diaphragm, the large liver (Hepar) was located cranial to the stomach and intestine, and was attached with abdominal surface of the diaphragm, so the parietal surface (Facies parietalis) of the stomach was attached to the visceral surface of the liver. A relatively large spleen was barely attached to the greater curvature of the stomach by the gastrosplenic ligament (Fig. 1).

The stomach was nearly located to the left of the median plane of the body and only the small part of the pylorus was located at the median line or slightly to the right side. The great curvature (Curvatura ventriculi major) of the stomach forms the convex border of the stomach and was extended from the fundus to the pyloric region and this curvature descended ventrocaudally to touch the lateral abdominal wall. The great curvature reaches to $3 \mathrm{~cm}$ in length while the lesser curvature (Curvatura ventriculi minor) reaches $1.5 \mathrm{~cm}$. The lesser curvature formed a nearly straight border of the stomach, which ran from the cardiac opening to the pyloric opening of the stomach.

The stomach was attached to the visceral surface of the liver from the $10^{\text {th }}$ to $13^{\text {th }}$ intercostal space, while the fundus was situated at the level of the $8^{\text {th }}$ rib. The pylorus was situated at the level of the $12^{\text {th }}$ intercostal space and directed dorsolaterally. The cardia was situated at the level of $7^{\text {th }}$ to $9^{\text {th }}$ intercostal space. 

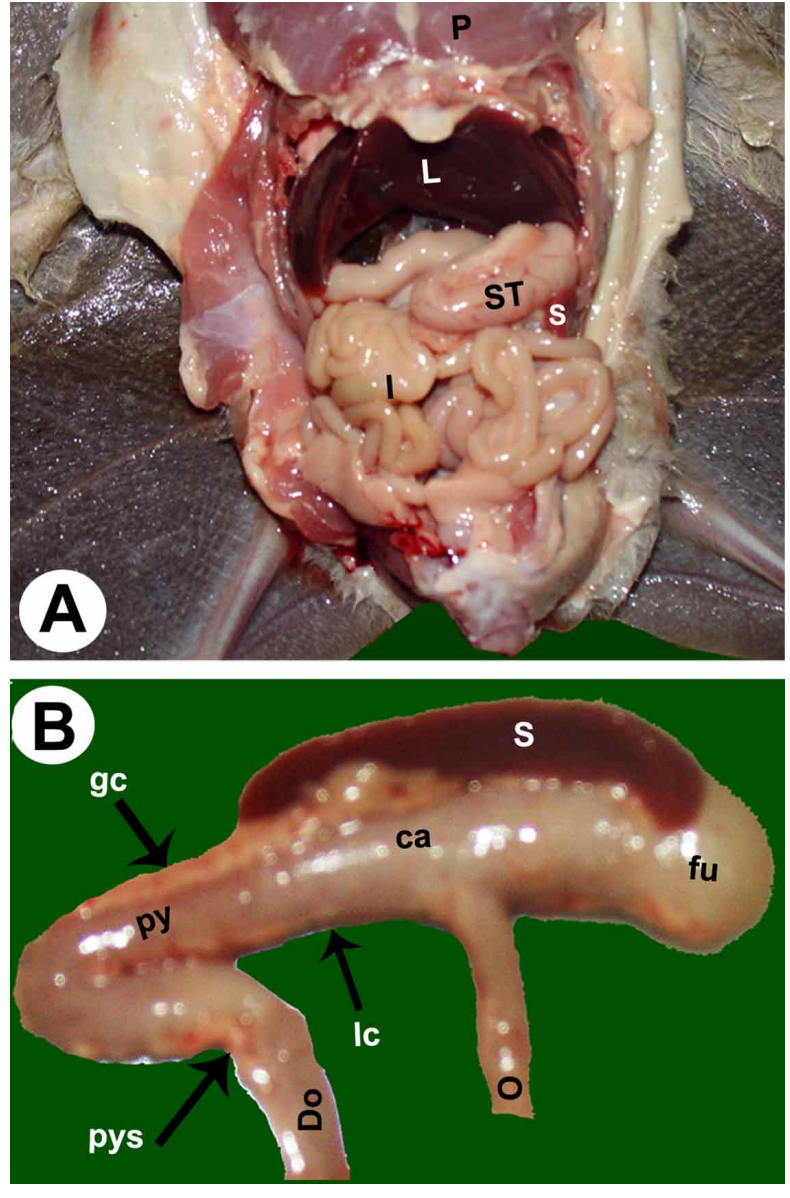

Fig. 1. A. Ventral view of the stomach in the abdominal cavity; B: external conformation of the stomach. To clarify; ST: stomach; S: spleen; L: liver; P: pectoral muscle; I: intestine; Fu, fundic region; ca: cardiac region; py: pyloric region; O: esophagus; Do: duodenum; pys: external pyloric constriction; gc: greater curvature; ic: lesser curvature.

The Egyptian fruit bat stomach was fixed in its position by its connection to the esophagus by the cardiac opening and to the duodenum by the pyloric opening, in addition to the pressure of the abdominal wall and the surrounding organs: liver, intestine, and spleen and there is a weak ligamentous fixation by the ill-developed lesser and greater omentum.

\section{Macroscopic study of the Egyptian fruit bat stomach:} Externally the stomach was $\mathrm{C}$-shaped with a long convex greater curvature and a short nearly straight lesser curvature, there was a short distance between the cardiac and the pyloric opening at about $1.4 \pm 0.2 \mathrm{~cm}$. The empty stomach was about $4 \pm 0.2 \mathrm{~cm}$ length at its longest part (from the fundic to the pyloric region), and $1.2 \pm 0.1 \mathrm{~cm}$ in width at the fundic which is the broadest region of the stomach. The stomach was divided into three regions; fundic (Fundus ventriculi), cardiac (Pars cardiaca) and pyloric (Pars pylorica) region (Fig. 1). The fundic region had a large diverticulum with blunt end, so it was named fundic cecal region. The two openings of the stomach (cardiac and pyloric opening) lied parallel to each other. The pyloric sphincter was externally marked by a slight constriction and a narrow band which encircles the tube (Fig. 1).

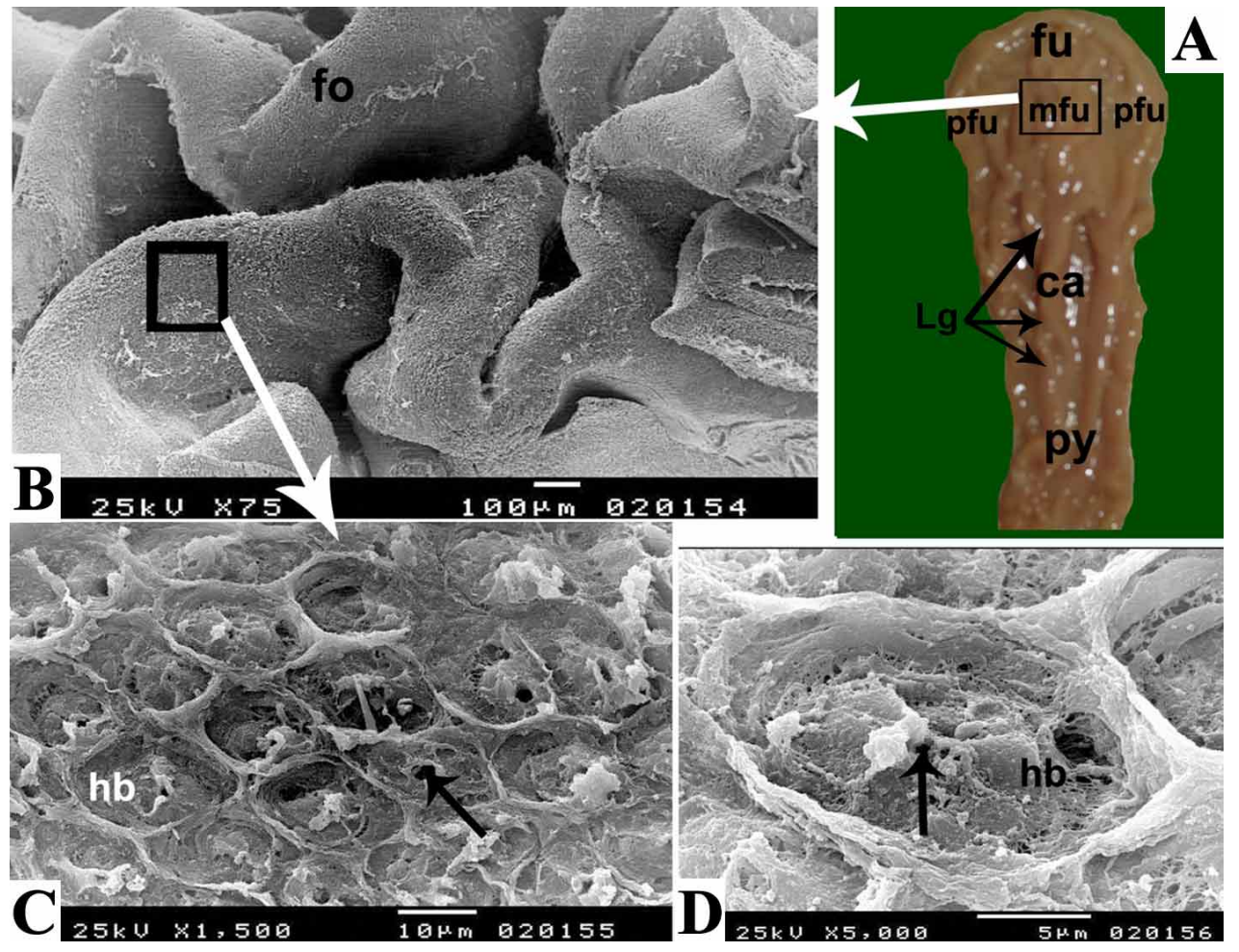

Fig. 2. A. Macroscopical view of the stomach to show; $\mathrm{Lg}$ : longitudinal rugae; fu: fundic region; ca: cardiac region; mfu: middle part of fundic region; pfu: peripherical part of fundic region. B: SEM of the mucosal surface of the fundic region at low magnification to show the folded surface (fo). C: SEM of the mucosal surface of the middle part of fundic region with high magnification to show the six-sided buildings similar to honeycomb (hb) which encircle the irregular elevated structures which contain in its middle part the gastric fosses (black arrow). D: high magnification of the sixsided buildings similar to honeycomb (hb) which encircle the irregular elevated structures which contain in its middle part the gastric fosses (black arrow). 
Internally, the stomach was tubular and unilocular with an elongate large cecal fundic part and a long narrow tubular pyloric part, while the cardiac part was small in size, so it was named cardiac vestibular part. The pyloric tubular part was long, and ended in a narrow junction with the duodenum due to presence of the pyloric sphincter $(M$. sphincter pylorica) but it was smaller in size if compared by the well-developed cardiac sphincter ( $M$. sphincter cardiae). The fundic cecal region was the large blind sac located left and dorsal to the cardia.

The superficial epithelium of the empty stomach was disposed in filiform form, with longitudinal rugaes (Fig. 2), that extended throughout the length of the stomach, their number were high but they were thin and branched in the fundic region, in addition to some diagonal and transverse rugaes which branched from the longitudinal rugae near the proximal part of this region of the stomach while there were 3 or 4 thick longitudinal not branched rugaes in the cardiac portion which extended to the pyloric region and began to disappear gradually from the middle of the pyloric region. The mucosa of the distended bat stomach was smooth.
Scanning electron microscopic studies: At low magnification, the gastric mucosal surface appears highly folded with grooves between it, exudate was found in these grooves (Fig. 2). The high magnification of the middle part of the fundic region appeared as many epithelial cells collected together and appeared as an irregular elevated structure surrounded by the mucosal crest, so the middle part appeared as six-sided buildings similar to honeycomb, in which there was a small gastric pit near to the center of the honeycomb buildings (Fig. 2). The region of the honeycomb buildings had numerous deep hexagonal and cylindrical fosses which probably trap the fluid part of digesta exposing it to an extensive surface area for digestion. The high magnification of the peripheral part of fundic region consisted of large epithelial cells (if compared to the previous in the middle part) collected together creating round elevated buildings, every building carry in its center a wide gastric pit (if compared to the previous in the middle part) (Fig. 3).

The large epithelial cells of the peripherical part had microvilli, at the entrance of the gastric fossa the number of the microvilli increased markedly in size and number (Fig. 3).

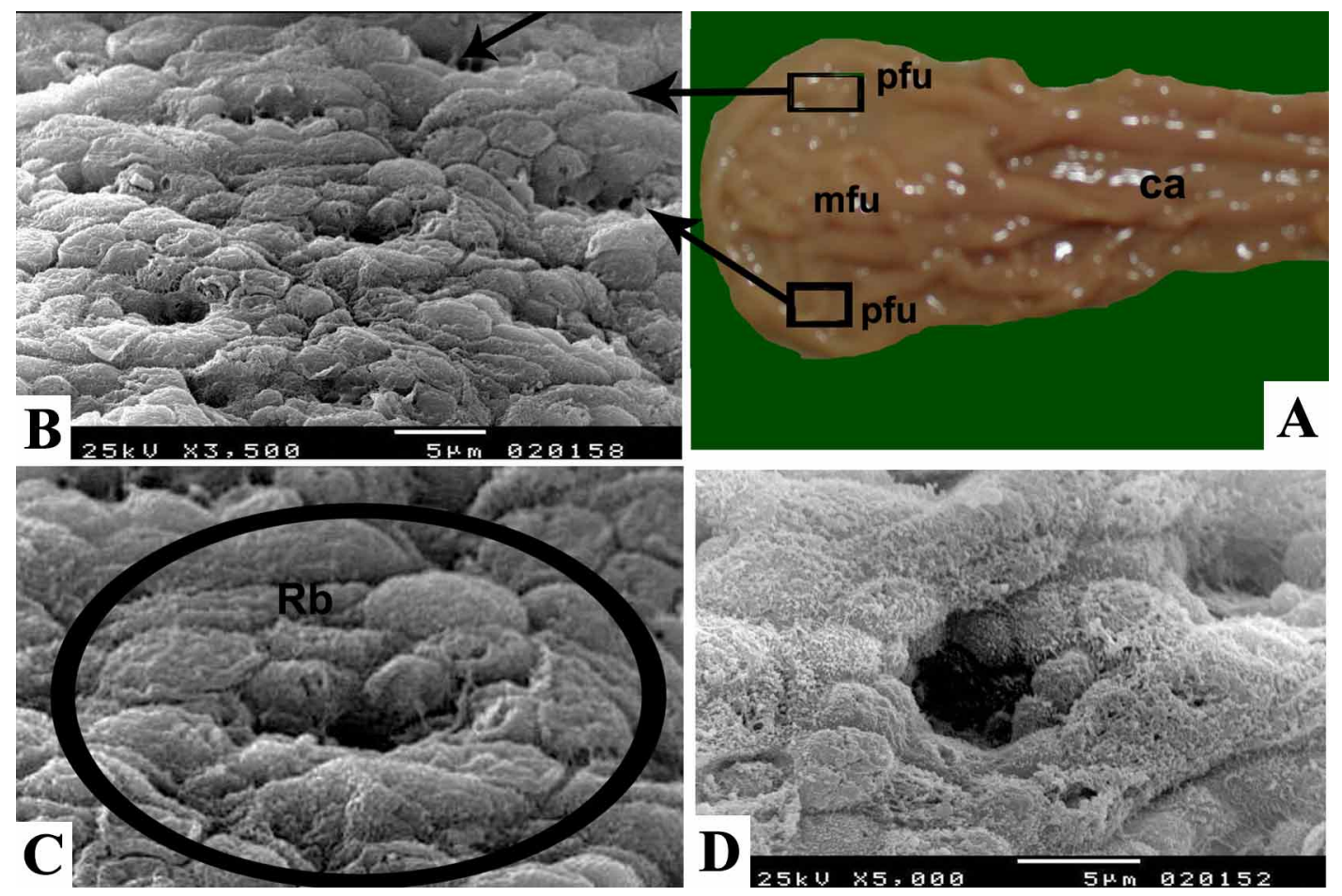

Fig. 3. A. Macroscopical view of the stomach to show; ca, cardiac region; mfu, middle part of fundic region; pfu, peripherical part of fundic region. B: SEM image at high magnification of the mucosa in the peripherical part of fundic region to show round elevated buildings, every building carries on its center wide gastric fosses (black arrow). C: SEM image of the same region with high magnification of elevated building with wide gastric fosses. D: SEM image of the same region with high magnification of elevated building with wide gastric fosses to show the microvilli on the epithelial cells. 
In cardiac region at high magnification many epithelial cells appeared collected together without a regular shape, in which there was a wide gastric fossa (Fig. 4). These epithelial cells had a large amounts of microvilli (Fig. 4).

In the pyloric region appeared a group of the epithelial cells collected to form elevated mountain areas which, from the dorsal view, take the shape of volcanic crater due to the presence in the center of deep and wide gastric pits. The gastric pits were surrounded by layers of epithelial cells of different levels which gave it the appearance of volcanic crater (Fig. 5). The epithelial cells were characterized by microtubercles and did not have microvilli (Fig. 5).

Histological studies: The wall of the stomach was composed of four layers (mucosa, submucosa, muscularis, and serosa). The mucosa of the empty stomach was cast into several longitudinal folds, while in the distended stomach, the mu-

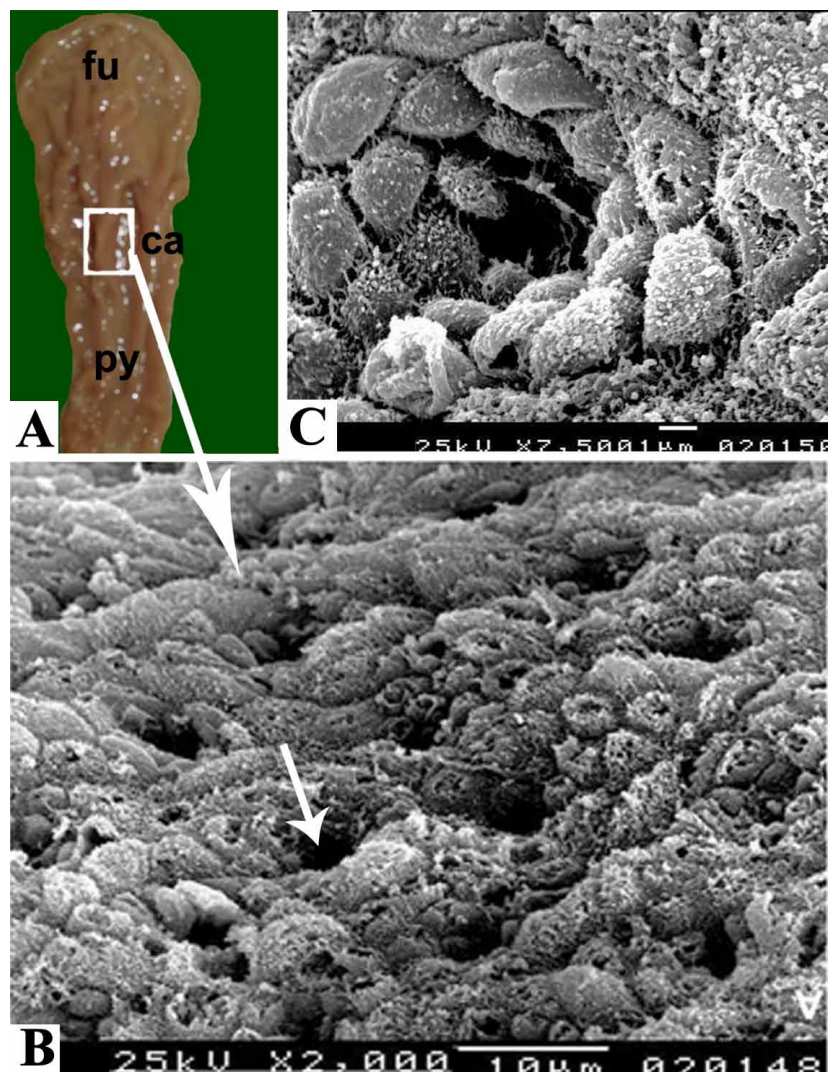

Fig. 4. A. Macroscopical view of the stomach to clarify; ca, cardiac region; fu, fundic region; py, pyloric region. B: SEM photograph of the mucosal surface of the cardiac region of the stomach with low magnification to show the epithelial cells were collected together without regular shape; in which there is a gastric fosse (white arrow). C: SEM photograph of the mucosal surface of the cardiac region of the stomach with high magnification to show the epithelial cells carry large amount of microvilli with wide gastric fosses. cosa was smooth. The mucosa consisted of the superficial epithelium (Figs. 6, 7), lamina propria (Fig. 6), and muscularis mucosae (Figs. 6 and 7). The epithelium of gastric mucosa was glandular in all the stomach and consisted of simple columnar mucous cells leading, in most cases, into numerous gastric fossa (Fig. 6) which are tubular infoldings of the superficial epithelium, which the tubular glands (Fig. $6)$ opened into. The tubular glands were embedded in a cellular lamina propria (Fig. 6). This loose connective tissue of the lamina propria was presented beneath the epithelium and filled the spaces between the gastric glands. A conspicuous feature of the rugae was the presence of thick muscularis mucosa (Figs. 6 and 7) which forms the core of the rugae.

The submucosa (Fig. 6) lied below the muscularis mucosae (Figs. 6 and 7) and consisted of numerous blood

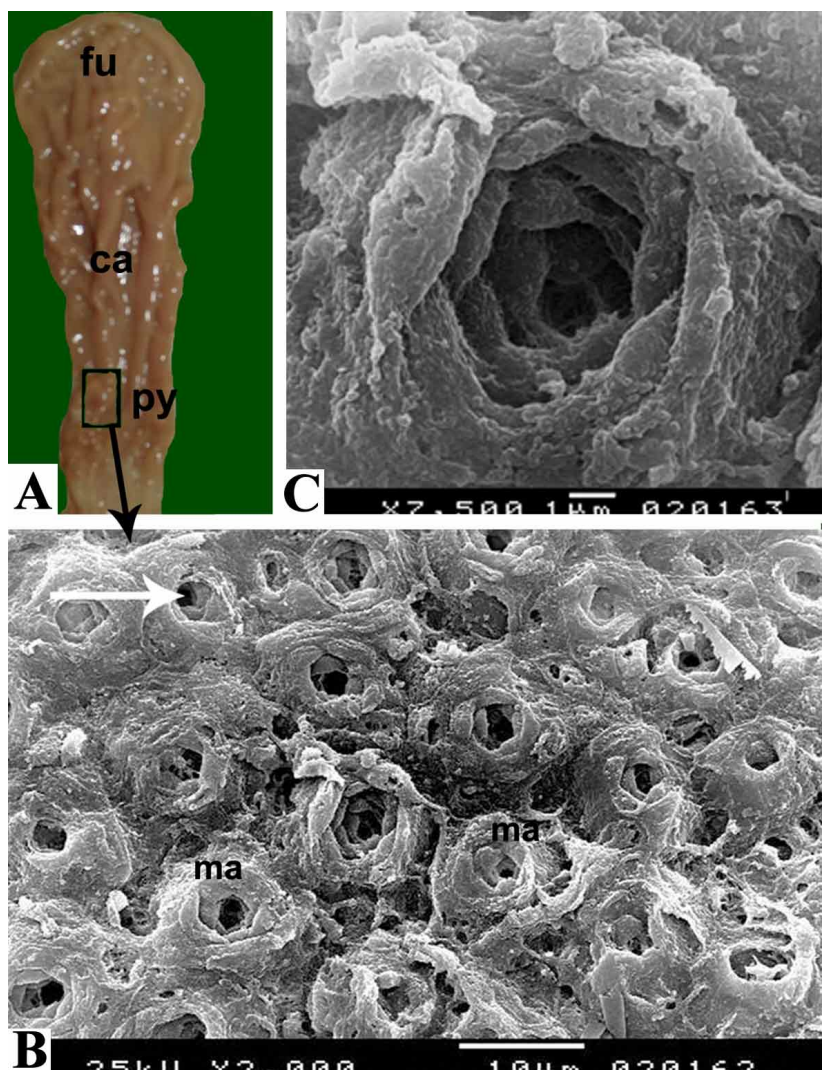

Fig. 5. A Macroscopical view of the stomach to show; fu, fundic region; ca, cardiac region; py, pyloric region. B: SEM photograph of the mucosal surface of the pyloric region stomach with low magnification of the pyloric region: to show the epithelial cells were collected to form this elevated mountains area (ma), take volcanic crater shape due to the presence of wide gastric fosses (white arrow). C: SEM photograph of the mucosal surface of the pyloric region of the stomach; with high magnification of the elevated mountains area to show the gastric fosses surrounded by a layer of epithelial cells of different level which give it the appearance of volcanic crater. 
vessels and lymphatics and connective tissue. The mucosa and submucosa thrown into numerous longitudinal rugae that traverse the entire length of the stomach between the gastro-esophaegeal and gastroduodenal junctions.

The tunica muscularis (Figs. 6 and 7) was composed of smooth muscle in two layers throughout the stomach; an outer longitudinal and an inner circular layer of muscles. The serosa (Figs. 6, 7) forms the outermost coat of the stomach and it was a thin outer layer of connective tissue that overlies the tunica muscularis.

There were gastric-associated lymphoid tissues (Fig. 7) in the stomach. Lymphoid nodules usually were composed of a germinal center (Fig. 7) with variously sized lymphocytes, large macrophages, and numerous reticular cells. Nodules are closed together with patches in the apical and middle part of the gastric longitudinal folds.

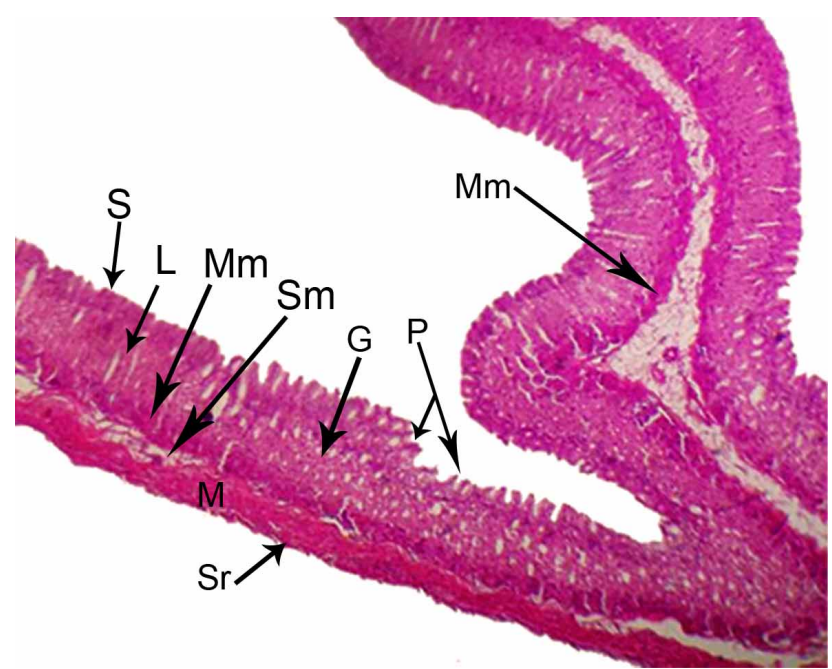

Fig. 6. Microscopic photography of the stomach to show: S: superficial epithelium; L: lamina propria; G: tubular gastric glands; Mm: muscularis mucosae: Sm: submucosa; P: gastric fosses; M: tunica muscularis; Sr: serosa.

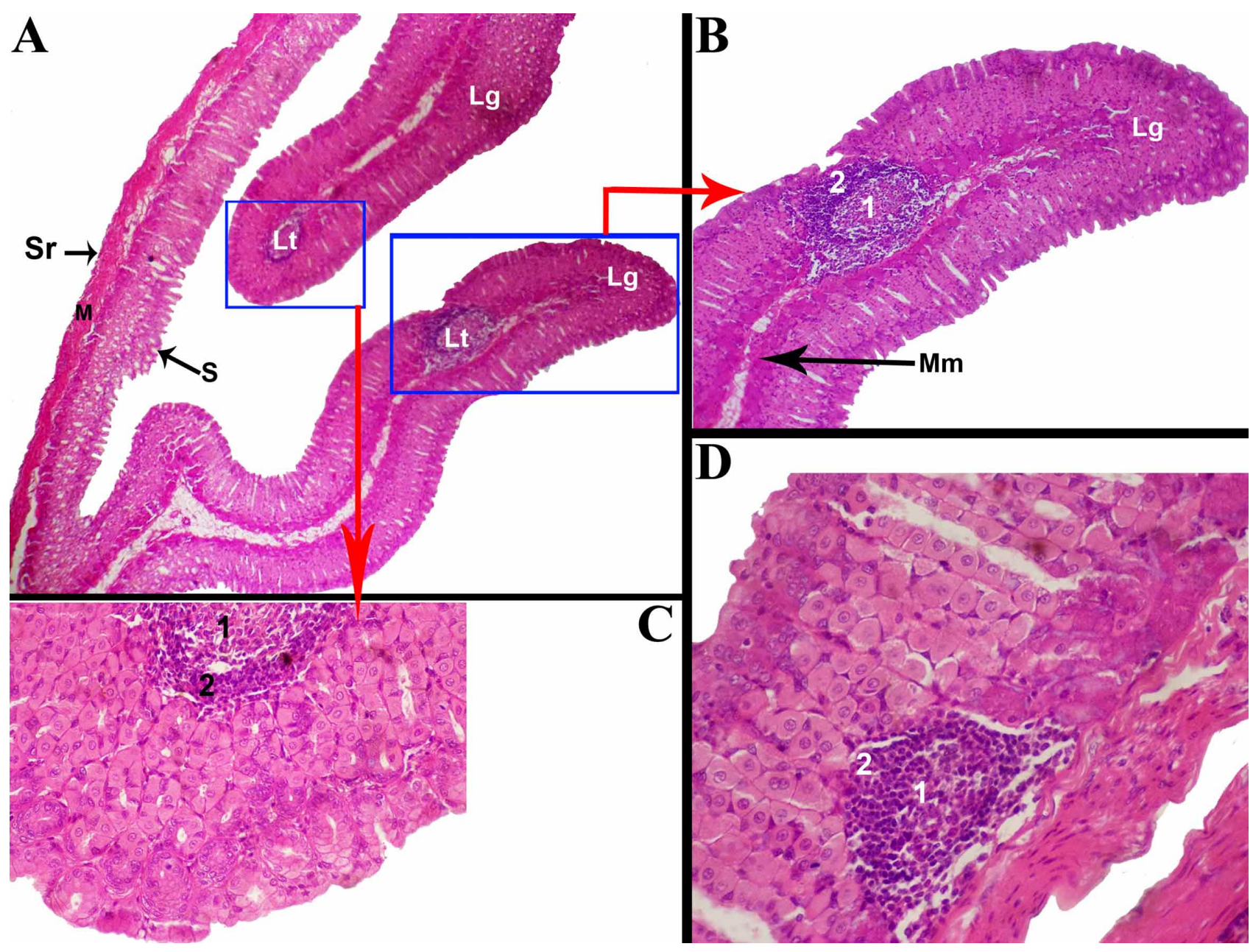

Fig. 7. Microscopic photographies of the stomach to show; S: superficial epithelium; Mm: muscularis mucosae; M: tunica muscularis; Sr: serosa; Lg: longitudinal rugae; Lt: gastric-associated lymphoid tissues; 1: germinal center; 2: subepithelial zone. 


\section{DISCUSSION}

According to our knowledge, this is the first whole anatomical description of the Egyptian fruit bat's stomach. In a descriptive analysis aimed to identify the normal histomorphological characters, the Egyptian fruit bats stomach were screened by light and scanning electron miscoscopes. The general objective of this study was to provide that there was species differences in gross morphology of the mammalian stomach, but there are similarities in some basic structures similar to previous descriptions (Huxley, 1865; Griffiths, 1965; Ghoshal \& Bal, 1989). Few gastric morphological differences were found in the Egyptian fruit bats as compared to other mammalian species. For example, there is an adaptation of the mammalian stomach shape according to many factors: nature of the feed, frequency of food intake, duration of food storage, body size and shape, in which Huxley gave the first description of the tubular, intestiniform of Desmodus rotundus stomach, however the present study revealed that the Egyptian fruit bat has C-shaped stomach, while Tedman \& Hall (1985) noted that the main body of fruit bats (Pteropus alecto and $P$. poliocephalus) stomach has a long cone shape, but (Park \& Hall, 1951) noted that the Macrotus has a pearshaped stomach, whereas in Artibeus, and Carollia, the stomach is triangular, while it has mallet- shaped stomach in Eptesicus, however, in Desmodus, which is blood sucking bat, the stomach is thin, long, and tubular.

The gastric adaption to feeding type is reflected also on the shape of parts of the stomach. The stomach was divided into three regions; fundic, cardiac and pyloric region as noted by in others works (Rouk \& Glass; Okon; Bhide; Forman, 1990; Makanya et al., 2001).

The present study agrees with Rouck \& Glass, 1970 in that the gross morphology and histology of bats stomach varies according to the type of diet with some taxonomic inclination. For example, Forman (1973) observed that the gastric modifications in frugivorous bats could respond to food variation, or adaptation to digestion of large quantities of plant material. In their evolution, bats are not truly herbivorous (Yalden \& Morris, 1975), but the present study confirmed that the Egyptian fruit bats fed as herbivorous animals. It is well known that the Chiroptera is unique, they exhibit a wide variety and they are very specific in feeding habits leading to the differences in the shape of the stomach they possess. The present study agrees with many published articles (Grassè, 1955; Schultz, 1965; Forman, 1972; Kamiya \& Pirlot; Okon; Bhide; Tedman \& Hall) that, there is a specific classification of the bats stomach according to its shape; the frugivorous species Megachiroptera and
Microchiroptera, has a well-developed cardiac vestibule and elongated fundic caecum with a narrow pyloric part, while in the present study, the Egyptian fruit bat's tubular stomach has an elongated fundic cecal region with a blunt end, and a long and narrow tubular pyloric part, with a small cardiac vestibular part. The present study and (Forman, 1972) confirmed that these characteristic of frugivorous species will then help in their adaptations to accumulate large quantities of bulky food material.

In the current study, the Egyptian fruit bat stomach laid to the left of the median plane and only the small part of the pylorus was located at the median line or slightly to the right side. The present study agrees with Tedman \& Hall in fruit bats (Pteropus alecto and P. poliocephalus) that, the pyloric sphincter is marked externally by a slight constriction and a narrow band which encircles the tube.

Our work reinforces the idea that gastric adaptation to feeding type is reflected also on the relationship between cardiac and fundic part of the stomach; as noted in many plant-feeding microchiropteran of family Phyllostomidae that have stomachs which vary in relative sizes of the cardiac and fundic parts (Forman et al., 1979; Forman, 1990). In Egyptian fruit bat, the stomach was characterized by the large fundic cecal region and a small cardiac vestibular region, which agree with (Forman, 1990) that noted that the stomach with large fundic part has small cardiac part, and vice versa. The present study noted that, there is a relationship between the feeding type and the internal structure of the stomach, in which the stomach of fruit eating bat has well-developed fundus, different to descriptions of the fundus of pteropodines and macroglossines (Tedman \& Hall; Forman, 1990). This suggests that in Egyptian fruit bat, the large fundic cecal part of the stomach acts as a major storage area for the fiber content of the fruit, while the cardiac part is the small one in all fruit eating bats, as noted in previous works (Forman $e t$ al., 1979; Forman, 1990) so this study suggests the idea that, the Egyptian fruit bat is considered a herbivorous animal. The fundic region of stomach with a large diverticulae with blunt end can help in digestion. Tedman \& Hall in $P$. poliocephalus and $P$. alecto noted that there are well developed fundic and cardiac regions which are closely held together by peritoneum, the fundic caecum is much longer than the cardiac vestibule in $P$. poliocephalus, but has similar length or is shorter in P. alecto.

Notably Robin 1881 \& Okon noted that the mucosal folds of bat stomach had three types; first type, has longitudinal and parallel folds as in insectivorous bats; second type, has similar folds but with numerous anastomoses in Desmodontidae, and third type has sponge-like folds in the frugivores. The present study agrees with Tedman \& Hall in 
P. poliocephalus and P. alecto, that, the stomach has filiform longitudinal rugaes, extended throughout the length of the stomach and differed along the length of the stomach, in which the numbers of the filiform longitudinal rugae are high but thin and branched in the fundus. In addition it is compartmentalized by diagonal and transverse rugae which branch from the longitudinal rugae near to the proximal part of this region of the stomach. Our study added that, the cardiac and pyloric region have 3 or 4 thick longitudinal not branched rugae, while Tedman \& Hall in P. poliocephalus and, noted that the rugae in the main part of the stomach were widely separated with few side branches and nearer the pylorus the rugae were reduced in height, and were much more numerous than in the rest of the stomach, while at the distal end of the pyloric sphincter the rugae were replaced by a mat of villi. In Desmodus (Park \& Hall) noted that there were delicate, filiform, longitudinal rugaes, while in the insect-eating bat, the rugae were uniform and narrow. Rouk \& Glass observed that the stomach of Desmodus rotundus has folds on the mucosa and submucosa that forms numerous thin, longitudinal and branching rugaes, while in Nectivore (Leptonycteris sanborni), the mucosa and submucosa were thrown into numerous longitudinal, short, branching, and anastomosing rugae, but in insectivores (Myotis velifr, Tadarida brasiliensis, and Antrozous pallidus), the rugae tend to be effaced in the elastic portion of the stomach when it is fully distended. Welldeveloped folds are found in the stomach of cats and dogs, while pigs have less evident infoldings (Banks, 1991).

The present study agrees with Nunn et al., (1990) that the gastric mucosal surface at low magnification of SEM appeared as a highly folded surface. In the present study, we showed for the first time at high magnification of the fundic cecal region that, there is a difference in the appearance of middle part from the peripherical part of the fundic cecal region; the middle part consists of many epithelial cells collected together creating irregular elevated structures, these structures were surrounded by mucosa crest, which gave the appearance of six-sided buildings similar to honeycomb, this is the first recorded of this disposition in all bats, but this honeycomb buildings was observed in the cranial part of the intestine of insectivorous horseshoe bat (Makanya \& Maina, 1994). On other hand, in the present study, the peripherical part of fundic cecal region have many large epithelial cells collected together creating round elevated buildings, also this is the first record of round elevated buildings in all bats. The present study showed for the first time at high magnification of the pyloric region that, there are groups of the epithelial cells collected to form elevated mountain area which takes the shape of volcanic crater due to presence of gastric fosses.

The basic histological structure of the bat stomach is similar in all bat species as noted in our study and by Rouk \&
Glass in five north and central American bats, the wall of the stomach is composed of the four layers (mucosa, submucosa, muscularis, and serosa). Our study agrees with the study of (Bhide) in the Rousettus leschenaultia where most of the rugae in the stomach have a core of muscularis mucosae.

The present study represented the first record of gastricassociated lymphoid tissue in the Egyptian fruit bat stomach, possible related to immunological protection. Forman (1974) noted that the gut-associated lymphoid tissue in general is not common in bats and added that the fruit eaters, nectar feeders, omnivores, and tropical insect eaters of the genus Molossus have better developed gut-associated lymphoid tissue in intestine. The present study shows that there are two shape of the gastric-associated lymphoid tissue but was not marked in a specific site in the stomach, but Forman noted that the nodules rarely had uniform shape within the intestine.

In conclusion, we found under the scanning electron microscopy, differences in the appearance of each part of stomach (cardiac, fundic and pyloric) and the more characteristic feature there is a difference of middle part from the peripherical part of the fundic region. The present study reported the first record of gastric-associated lymphoid tissue in the Egyptian fruit bat stomach.

ABUMANDOUR, M. M. A. \& PÉREZ, W. Estudios morfológico y de microscopía electrónica de barrido del estómago del murciélago egipcio de la fruta (Rousettus aegyptiacus). Int. J. Morphol., 35(1):242-250, 2017.

RESUMEN: En este trabajo se estudiaron las características histomorfológicas del estómago del murciélago egipcio de la fruta, a través de microscopía electrónica de barrido. Para el estudio se utilizaron 14 estómagos de murciélagos egipcios de la fruta, adultos sanos y de ambos sexos. El estómago era tubular con una región fúndica alargada y una región pilórica larga y estrecha. Internamente, el epitelio era filiforme y las rugas longitudinales se extendían a lo largo del estómago, su número era alto, delgado y ramificado en la región fúndica, mientras que en las regiones del cardias y pilórica alcanzaban un número de 3 o 4 , gruesos, longitudinales y no ramificados. Al microscopio electrónico de barrido se encontraron diferencias en la apariencia de la parte media respecto a la parte periférica de la región fúndica, al igual que la aparición de estructuras en nido de abeja en la parte media, diferente a las formaciones redondas elevadas observadas en la periferia de la región fúndica. A mayor ampliación de la región del cardias, se observó una agregación de células epiteliales sin forma regular, mientras que en la región pilórica, se encontraron áreas elevadas. Concluimos que los estómagos del murciélago egipcio de la fruta presentan caracteres especiales diferentes a la de otros mamíferos.

PALABRAS CLAVE: Anatomía; Quiroptera; Sistema digestivo; Microscopía electrónico de barrido. 


\section{REFERENCES}

Abumandour, M. M. \& El-Bakary, R. M. Morphological and scanning electron microscopic studies of the tongue of the Egyptian fruit bat (Rousettus aegyptiacus) and their lingual adaptation for its feeding habits. Vet. Res. Commun., 37(3):229-38, 2013.

Abumandour, M. M. Morphological comparison of the filiform papillae of New Zealand white rabbits (Oryctolagus cuniculus) as domestic mammals and Egyptian fruit bat (Rousettus aegyptiacus) as wild mammals using scanning electron microscopic specimens. Int. J. Morphol., 32(4):1497-17, 2014.

Altringham, J. D. Bats. Biology and Behaviour. New York, Oxford University Press, 1996.

Bancroft, J. D. \& Cook, H. C. Manual of Histological Techniques. New York, Churchill Livingstone, 1984.

Banks, W. J. Histologia Veterinaria Aplicada. $2^{\text {nd }}$ ed. São Paulo, Manole, 1991.

Bhide, S. A. Observations on the anatomy, histology and histochemistry of the stomach of the vespertilionid bat, Miniopterus schreibersii (Kuhl). Proc. Indian Acad. Sci., 88:563-74, 1979.

Forman, G. L. Comparative morphological and histochemical studies of stomachs of selected American bats. Univ. Kans. Sci. Bull., 49:591729,1972

Forman, G. L. Studies of gastric morphology in North American Chiroptera (Emballonuridae, Noctilionidae and Phyllostomatidae). J. Mammal., 54(4):909-23, 1973

Forman, G. L. Comparative macro- and micro-anatomy of stomachs of macroglossine bats (Megachiroptera: Pteropodidae). J. Mammal., 71(4):555-65, 1990.

Forman, G. L.; Phillips, C. J. \& Rouk, C. S. Alimentary Tract. In: Baker, R. J.; Jones Jr., J. K. \& Carter, D. C. (Eds.). Biology of Bats of the New World Family Phyllostomatidae. Part III. Lubbock, Special Publication of the Museum, Texas Tech University, 1979. pp.205-27.

Ghoshal, N. G. \& Bal, H. S. Comparative morphology of the stomach of some laboratory mammals. Lab. Anim., 23(1):21-9, 1989.

Grassé, P. P. Traité de Zoologie. Paris, Masson, 1955.

Griffiths, M. Digestion, growth and nitrogen balance in an egg-laying mammal, Tachyglossus aculeatus (shaw). Comp. Biochem. Physiol., 14:357-75, 1965.

Halstead, L. B. Fruit Bat (Eidolon helvum). Dissection Guides of Common Tropical Animals. Benin City, Ethiope Pub. House, 1975.

Huxley, T. H. On the structure of the stomach in desmodus rufus. Proc. Zool. Soc. Lond., 35:386-90, 1865.

Kamiya, T. \& Pirlot, P. Comparative gastric morphology of old-world bats. Part 1. In light microscopy. J. Mammal. Soc. Jpn., 6(4):145-54, 1975.

Madkour, G. Structure of the penis in the fruit bat Rousettus aegyptiacus (Megachiroptera). J. Mammal., 57(4):769-71, 1976.

Madkour, G. A. Comparative study of certain features of the alimentary canal and disposition of the viscera in Egyptian bats. Ann. Zool. (Agra.), 13:63-81, 1977.

Madkour, G. A.; Hammouda, E. M. \& Ibrahim, I. G. Histology of the alimentary tract of two common Egyptian bats. Ann. Zool. (Agra.), 19:53-74, 1982.

Makanya, A. N. \& Maina, J. N. The morphology of the intestine of the insectivorous horseshoe bat (Rhinolophus hildebrandti, Peters): a scanning electron and light microscopic study. Afr. J. Ecol., 32(2):15868, 1994.

Makanya, A. N.; Self, T. J.; Warui, C. N. \& Mwangi, D. K. Gut morphology and morphometry in the epauletted Wahlberg's fruit bat (Epomophorus wahlbergi, Sundevall, 1846). Acta Biol. Hung., 52(1):75-89, 2001.

Martinez del Rio, C.; Cork, S. J. \& Karasov, W. H. Modelling Gut Function: An Introduction. In: Chivers, D. J. \& Langer, P. (Eds.). The Digestive System in Mammals - Food, Form and Function. Cambridge, Cambridge University Press, 1994. pp.25-53.
Nunn, S.; Gilmore, R. S.; Dodge, J. A. \& Carr, K. E. Exudate variation in the rabbit gastrointestinal tract: a scanning electron microscope study. J. Anat., 170:87-98, 1990.

Okon, E. E. Functional anatomy of the alimentary canal in the fruit bat, Eidolon helvum, and the insect bat, Tadarida nigeriae. Acta Zool., 58(2):83-93, 1977

Park, H. \& Hall, R. The gross anatomy of the tongues and stomachs of eight New World bats. Trans. Kans. Acad. Sci., 54(1):64-72, 1951.

Robin, H. A. Recherches Anatomiques Sur Less Mammiferes De L'ordre Des Chiropteres. Thèse Facultadé des Sciences de Paris. Paris, Masson, 1881.

Rouk, C. S. \& Glass, B. P. Comparative gastric histology of five North and Central American bats. J. Mammal., 51(3):455-90, 1970.

Schultz, W. Studien über den Magen-Darm-Kanal der Chiropteren. Z. Wiss. Zool., 171:240-391, 1965.

Schultz, W. Einige Bemerkungen zum Bau des Verdauungstraktes und der systematischen Stellung des Spitzzahnflughundes, Harpyionycteris whiteheadi Thomas, 1896 (Megachiroptera). Z. Säugetierkunde, 35:8188, 1970.

Tedman, R. A. \& Hall, L. S. The Morphology of the Gastrointestinal Tract and Food Transit Time in the Fruit Bats Pteropus alecto and $P$. poliocephalus (Megachiroptera). Aust. J. Zool., 33(5):625-40, 1985.

Wilson, D. E. \& Reeder, D. M. Mammal Species of the World. A Taxonomic and Geographic Reference. $2^{\text {nd }}$ ed. Washington, Smithsonian Institution Press, 1993.

Yalden, D. W. \& Morris, P. A. The Lives of Bats. Newton Abbot, David \& Charles, 1975.

Corresponding author:

Mohamed M. A. Abumandour

Assistant Professor of Anatomy and Embryology

Faculty of Veterinary Medicine

Alexandria University

Anatomy and Embryology Department

Post Box: 22785,

Rashid, Edfina

Behera

EGYPT

Telephone: +201000322937

Fax: $\quad+20452960450$

Email address: m.abumandour@yahoo.com

Received: 13-07-2016

Accepted: 23-11-2016 